\title{
Efficacy of Fumagillin DCH against experimentally induced Loma salmonae (Microsporea) infections in chinook salmon Oncorhynchus tshawytscha
}

\author{
Michael L. Kent, Sheila C. Dawe \\ Department of Fisheries and Oceans, Biological Sciences Branch, Pacific Biological Station, Nanaimo, British Columbia, Canada V9R 5K6
}

\begin{abstract}
Loma salmonae (Microsporea) is a serious gill pathogen of seawater pen-reared chinook salmon Oncorhynchus tshawytscha. Fumagillin DCH has been used to control other microsporean and myxosporean diseases of fishes, and the efficacy of this drug for controlling $L$. salmonae infections was investigated. Chinook salmon were experimentally infected with $L$. salmonae in seawater tanks. At 1 wk post initial exposure, 2 tanks of 12 fish each were fed Fumagillin DCH in the diet at $10 \mathrm{mg}$ drug $\mathrm{kg}^{-1}$ fish $\mathrm{d}^{-1}$ for $30 \mathrm{~d}$, and 2 other tanks of exposed fish were maintained as non-treated controls. None of the surviving 22 Fumagillin-treated fish exhibited $L$. salmonae infections when examined at $44 \mathrm{~d}$ post initial exposure, while 13 of 21 untreated fish were infected. This preliminary study suggests that Fumagillin DCH may be a useful therapeutant for controlling $L$. salmonae infections.
\end{abstract}

KEY WORDS: Loma salmonae Microsporea - Fumagillin

Loma salmonae (Putz, Hoffman \& Dunbar, 1965) (Microsporea) infects the gills and other vascularized tissues of wild and hatchery-reared salmonids in fresh water throughout the Pacific Northwest of North America (Wales \& Wolf 1955, Putz et al. 1965, Putz \& McLaughlin 1970, Morrison \& Sprague 1981, 1983, Hauck 1984, Magor 1987). Although most reports of $L$. salmonae have been from fishes in fresh water, infections can persist after fish are transferred to seawater (Wood 1974). In addition, the parasite can be transmitted in seawater (Kent et al. 1995). In seawater netpens, severe gill lesions associated with the infection have been observed in coho salmon Oncorhynchus kisutch (Kent et al. 1989, Speare et al. 1989) and chinook salmon Oncorhynchus tshawytscha (Kent 1992). Chemotherapeutants are not routinely used for treating microsporean infections in fish; however, Fumagillin DCH may be a good candidate for this purpose. Fumagillin $\mathrm{DCH}$ is an antimicrobial agent used pri- marily for treating Nosema apis (Microsporea) infections in honey bees. The drug apparently acts by inhibiting RNA synthesis (Jaronski 1972). Kano et al. (1982) reported that Fumagillin DCH was effective against the microsporean Pleistophora anguillarum in eels Anguilla japonica and the drug has been used to control Enterocytozoon salmonis infections in chinook salmon (Hedrick et al. 1991). There have also been reports on successful treatment of various myxosporean diseases of fishes, including those affecting salmonids (Molnár et al. 1987. Hedrick et al. 1988, Székely et al. 1988, Wishkovsky et al. 1990, Yokoyama et al. 1990, El-Matbouli \& Hoffmann 1991, SitjàBobadilla \& Alvarez-Pellitero 1992).

Based on these reports, about 3 to $10 \mathrm{mg}$ Fumagillin $\mathrm{kg}^{-1}$ fish $\mathrm{d}^{-1}$ is the recommended dose for treating salmonids. Higher concentrations or prolonged treatment (e.g. 30 to 60 d) may cause toxic side effects (Laurén et al. 1989, Wishkovsky et al. 1990). The drug is not heat stable. Therefore, it is recommended that the feed be coated with the drug, instead of incorporated in the feed during milling. The following laboratory study was conducted to determine if Fumagillin $\mathrm{DCH}$ is a potential candidate drug for the control of Loma salmonae infections in chinook salmon.

Materials and methods. A total of 48 chinook salmon (average weight $22 \mathrm{~g}$ ) were divided into 4 groups of 12 fish each and were placed in $14 \mathrm{l}$ tanks with running seawater at $15^{\circ} \mathrm{C}$. The fish were reared on dechlorinated tap water before the experiment and previous examination demonstrated that the stock was free of Loma salmonae. Fish in each tank were exposed to L. salmonae as follows. Approximately $5 \mathrm{~g}$ of chinook salmon gill tissue containing numerous L. salmonae xenomas (collected from a commercial netpen site) 
were placed in sterile saline, chopped finely and introduced to the aquarium. The water flow to each tank was turned off for $2 \mathrm{~h}$ to enhance contact of the parasite with the fish. Fish were exposed by this method 3 times on alternating days at the beginning of the experiments. We have successfully used this method for experimentally infecting fish with $L$. salmonae in another study (Kent et al. 1995).

Fish in 2 of the 4 tanks were treated with Fumagillin $\mathrm{DCH}$ in the feed at $10 \mathrm{mg}$ drug $\mathrm{kg}^{-1}$ fish $\mathrm{d}^{-1}$ for $30 \mathrm{~d}$, starting $1 \mathrm{wk}$ after initial exposure to Loma salmonae. Fumagillin DCH is 60 to $70 \%$ active, and thus the fish were treated with 6 to $7 \mathrm{mg}$ active drug $\mathrm{kg}^{-1}$ fish $\mathrm{d}^{-1}$. Treated feed was prepared by dissolving Fumagillin DCH in $95 \%$ ethanol and spraying commercial pellets with the solution. The concentration of the drug in the feed was $1 \mathrm{~g}^{\mathrm{d}} \mathrm{ug} \mathrm{kg}^{-1}$ feed, and fish were fed at $1 \%$ body wt $d^{-1}$. Fish in the 2 other tanks were fed the same diet (at $1 \%$ body wt $\mathrm{d}^{-1}$ ) that was untreated.

All fish were examined $1 \mathrm{wk}$ after the treatment was completed. Fish were euthanized with an overdose of MS-222 (tricaine methanesulfonate). Four gill arches were collected from each fish and preserved in Davidson's solution. Histological sections were prepared from each arch, stained with hematoxylin and eosin, and examined for the presence of Loma salmonae.

Results. Three untreated fish died at 15, 19 and $27 \mathrm{~d}$ after initial exposure, and 2 treated fish died on 26 and $41 \mathrm{~d}$ after initial exposure. The remaining fish in all tanks were euthanized at $44 \mathrm{~d}$ post initial exposure and gills were examined. None of the Fumagillin-treated fish exhibited Loma salmonae infections. Eight of 11 fish from one non-treated tank and 5 of 11 fish in the other non-treated tank were infected with $L$. salmonae. Numerous xenomas filled with the spores were observed in gill filaments and lamellae in histological sections. The mean weights of the treated fish in each of the 2 tanks were $23.1 \pm 3.8 \mathrm{~g}$ and $23.5 \pm 6.8 \mathrm{~g}$, and the mean weights in the control (untreated) tanks were $26.1 \pm 6.8 \mathrm{~g}$ and $25.5 \pm 8.9 \mathrm{~g}$. One-way analysis of variance revealed no significant differences in the weights of fish among tanks $(p<0.05)$.

Discussion. This study indicates that oral treatment with Fumagillin is an effective method for controlling Loma salmonae infections in salmon, and is the first report on chemical treatment of $L$. Salmonae infections. Various toxic side effects have been reported in salmonids fed high doses of Fumagillin DCH (Hedrick et al. 1988, Laurén et al. 1989). Hedrick et al. (1988) reported depletion of hematopoietic cells in the kidney and vacuolation of the renal epithelium in chinook salmon fed Fumagillin DCH at $10 \mathrm{mg}$ drug $\mathrm{kg}^{-1}$ fish $\mathrm{d}^{-1}$ for $7 \mathrm{wk}$. Wishkovsky et al. (1990) reported similar changes in rainbow trout Oncorhynchus mykiss fed the drug at 7.5 to 10 or 15 to $20 \mathrm{mg}$ drug $\mathrm{kg}^{-1}$ fish $\mathrm{d}^{-1}$ for $4 \mathrm{wk}$, and the spleen and anterior kidney were grossly reduced in size in some of these fish after $8 \mathrm{wk}$ In another study, rainbow trout fed at 3.75 or $15 \mathrm{mg}$ drug $\mathrm{kg}^{-1}$ fish $\mathrm{d}^{-1}$ for $60 \mathrm{~d}$ also showed degenerative changes in hematopoietic tissue and reduced hematocrit values. Furthermore, prolonged treatment with Fumagillin DCH at high levels (e.g. 15 to $20 \mathrm{mg}$ drug $\mathrm{kg}^{-1}$ fish $\mathrm{d}^{-1}$ ) may cause a reduction in growth in rainbow trout (Wishkovsky et al. 1990). In our study, no toxic side effects attributable to the Fumagillin treatment were observed, and mortality and final average weights were similar in both groups. However, our study was carried out for only $45 \mathrm{~d}$ after exposure to the parasite and fish were fed at a reduced level to ensure that all the Fumagillin-treated feed was eaten.

Although results from this preliminary study are encouraging, further research is needed to determine the precise treatment regime for controlling Loma salmonae (and other microsporean and myxosporean infections) in salmon without inducing significant toxic side effects. The fish were treated shortly after experimental $L$. salmonae infection, and it is unknown if the drug would be efficacious if applied during advanced infections in which xenomas are either fully formed or in a state of degeneration.

Acknowledgements. We thank Drs L. Margolis and T P. T Evelyn for review of the manuscript.

\section{LITERATURE CITED}

El-Matbouli, M., Hoffmann, R. W. (1991). Prevention of experimentally induced whirling disease in rainbow trout Oncorhynchus mykiss by Fumagillin. Dis. aquat. Org. 10: $109-113$

Hauck, A. K. (1984). A mortality and associated tissue reactions of chinook salmon, Oncorhynchus tshawytscha (Walbaum), caused by the microsporidan Loma sp. J. Fish Dis. 7: 217-229

Hedrick, R P., Groff, J. M., Baxa, D. V (1991). Experimental infections with Enterocytozoon salmonis Chilmonczyk, Cox. Hedrick (Microsporea): and intranuclear microsporidium of chinook salmon Oncorhynchus tshawytscha. Dis. aquat. Org. 10: 103-108

Hedrick, R. P., Groff, J M., Foley, P., McDowell, T (1988) Oral administration of Fumagillin DCH protects chinook salmon Oncorhynchus tshawytscha from experimentallyinduced proliferative kidney disease. Dis. aquat. Org. 4 $1.65-168$

Jaronski, S. T (1972). Cytochemical evidence for RNA synthesis inhibition by fumagillin. J. Antibiot. 6: 327-331

Kano, T., Okauchi, T., Fukui, H. (1982). Studies on Pleistophora infection in eel, Anguilla japonica - II. Prelimunary tests for application of Fumagillin. Fish Pathol. 17: $107-114$

Kent, M. L. (1992). Diseases of seawater netpen-reared salmonid fishes in the Pacific Northwest. Can Spec. Publ. Fish Aquat. Sci. 116

Kent, M. L., Dawe, S. C., Speare, D. J. (1995). Transmission of Loma salmonae (Microsporea) to chinook salmon (Onco- 
rhynchus tshawytscha) in sea water. Can. Vet. J. (in press) Kent, M. L., Elliot, D. G., Groff, J. M., Hedrick, R. P. (1989) Loma salmonae (Protozod: Microspora) infections in seawater reared coho salmon Oncorhynchus kisutch. Aquaculture 80: 211-222

Laurén, D. J., Wishkovsky, A., Groff, J. M., Hedrick, R. P., Hinton, D. E. (1989). Toxicity and pharmacokinetics of the antibiotic Fumagillin in yearling rainbow trout (Salmo gairdneri). Toxicol appl. Pharmacol. 98: 444-453

Magor, B. G. (1987). First report of Loma sp. (Microsporidia) in juvenile coho salmon (Oncorhynchus kisutch) from Vancouver Island, British Columbia. Can. J. Zool. 65: 751-752

Molnár, K., Baska, F. Székely, C. (1987). Fumagillin, an efficacious drug against renal sphaerosporosis of the common carp Cyprinus carpio. Dis. aquat. Org. 2: 187-190

Morrison, C. M., Spraque, V. (1981). Microsporidian parasites in the gills of salmonid fishes. J. Fish Dis. 4: 371-386

Morrison, C. M. Sprague, V (1983). Loma salmonae (Putz, Hoffman and Dunbar, 1965) in the rainbow trout, Salmo gairdnerj Richardson, and L. fontinalis sp. nov. (Microsporida) in the brook trout, Salvelinus fontinalis (Mitchell). J. Fish Dis. 6: 345-353

Putz, R. E., Hoffman, G. L., Dunbar, C. E. (1965). Two new species of Plistophora (Microsporidea) from North American fish with a synopsis of Microsporidea of freshwater and euryhaline fishes. J. Protozool. 12: 228-236

Putz, R. E., McLaughlin, J. J. A. (1970). The biology of Nosematidae (Microsporida) from freshwater and euryhaline fishes. In: Snieszko, S. F. (ed.) A symposium on diseases of

Responsible Subject Editor: W. Körting, Hannover, Germany fishes and shellfishes. Spec. Publ No. 5, American Fisheries Society, Washington, DC, p. 124-132

Sitjà-Bobadilla, A., Alvarez-Pellitero, P. (1992). Effect of Fumagillin treatment on sea bass Dicentrarchus labrax parasitized by Sphaerospora lesticularis (Myxosporea: Bivalvulida). Dis. aquat. Org 14:171-178

Speare, D. J., Brackett, J., Ferguson, H. W. (1989). Sequential pathology of the gills of coho salmon with a combined diatom and microsporidian infection. Can. Vet. J. 30: $571-575$

Székely, Cs., Molnár, K., Baska, F. (1988). Efficacy of Fumagillin against Myxidium giardi Cépéde, 1906 infection of the European eel (Anguilla anguilla): new observations on myxidiosis of imported class eels. Acta. vet. hung. 36: $239-246$

Wales, J. H., Wolf, H. (1955). Three protozoan diseases of trout in California. Calif. Fish Game 4 1. 183--187

Wishkovsky, A., Groff, J. M., Lauren, D. J., Toth, R. J., Hedrick, R. P. (1990). Efficacy of Fumagillin against proliferative kidney disease and its toxic side effects in rainbow trout (Oncorhynchus mykiss) fingerlings. Fish Pathol. 25: $141-146$

Wood, J. W. (1974). Diseases of Pacific salmon, their prevention and treatment. State of Washington, Dept Fish., Olympia

Yokoyama, H., Ogawa, K., Wakabayashi, H. (1990). Chemotherapy with fumagillin and toltrazuril against kidney enlargement disease of goldfish caused by the myxosporean Hoferellus carassii. Fish Pathol 25: 157-163

Manuscript first received: July 10,1994

Revised version accepted: September 19, 1994 